\title{
Historic seismicity near the source zone of the great 2008 Wenchuan earthquake: Implications for seismic hazards
}

\author{
Wang-Ping Chen ${ }^{\mathrm{a}, 1}, *$, Leslie Hsu ${ }^{\mathrm{b}}$ \\ a Department of Ocean Science and Engineering, Zhejiang University, Hangzhou, China \\ b Lamont-Doherty Earth Observatory, Columbia University, Palisades, NY 10964, USA
}

\section{A R T I C L E I N F O}

\section{Article history:}

Received 3 September 2011

Received in revised form 20 August 2012

Accepted 25 August 2012

Available online $\mathrm{xxxx}$

\section{Keywords:}

Historic seismicity

Wenchuan earthquake

Eastern Tibet

Longmen Shan thrust

Sichuan basin

\begin{abstract}
A B S T R A C T
In the past 500 years, 14 historical earthquakes, including one that caused a maximum intensity of IX, occurred over a distance of more than $300 \mathrm{~km}$ along the Longmen Shan thrust belt, including portions that did not rupture during the devastating Wenchuan earthquake sequence of May 12, 2008. Estimated locations of epicenters and trends of faulting during historical events complement information gathered after the 2008 sequence. In particular, in addition to the two fault splays that ruptured in 2008, there are additional seismogenic faults across the Longmen Shan belt, including those in the hinterland and in the foreland. In the latter case, the occurrence of moderate-sized historical earthquakes and the disproportionally wide region of reported damage in the Sichuan basin from large events within the Longmen Shan belt, probably an effect of low attenuation in the stable basin, calls for attention to the potential of seismic hazard in the heavily populated Chengdu basin. Moreover, long recurrence-intervals of great events, estimated from trenching of colluvium along the ruptures of the 2008 sequence, should not be taken as reliable estimates for somewhat smaller, but nonetheless highly destructive events along the Longmen Shan thrust belt.
\end{abstract}

(c) 2012 Elsevier B.V. All rights reserved.

\section{Introduction}

The devastating Wenchuan earthquake sequence of 2008 occurred along the Longmen Shan fold-and-thrust belt on the eastern margin of the Tibetan plateau (Fig. 1). The origin, evolution, and active deformation of the Himalayan-Tibetan orogen have long been a focus of intense basic research [e.g., Chen et al., 2010, 2012; Yin and Harrison, 2000; and references therein]. The Wenchuan sequence highlighted the immediate relevance of basic research to hazard mitigation and vice versa.

Prior to the occurrence of the 2008 sequence, the prevailing view was that the Longmen Shan and much of eastern Tibet attained high elevation through eastward, ductile flow of the lower Tibetan crust (e.g., Bird, 1991; Royden et al., 1997). This notion seems consistent with the observation that both geodetic (based on GPS) and geomorphic studies showed a low rate of convergence across the Longmen Shan belt (less than 3 mm/yr; [e.g., Densmore et al., 2007; Meade, 2007; Shen et al., 2005]). In addition, in the foreland of Longmen Shan, a typical foreland sedimentary basin, associated with plate flexure due to tectonic loading of the mountain belt, appears absent [e.g., Burchfiel et al., 1995].

However, large displacement along reverse faults during the 2008 sequence is strong evidence that seismogenic shortening across the

\footnotetext{
* Corresponding author.

E-mail address: wpchen@uiuc.edu (W.-P. Chen).

${ }^{1}$ Formerly at Department of Geology, University of Illinois, Urbana, IL 61821, USA.
}

Longmen Shan belt is an important component of active deformation. Results from studies of seismic moment release, patterns of ground deformation, and field surveys of surface ruptures point to two sub-parallel splays of rupture whose trends generally follow that of the Longmen Shan belt (Fig. 1; [e.g., Nakamura et al., 2010; Wang et al., 2011; Xu et al., 2009]).

The two splays, the Beichuan-Yingxiu and the Pengguan/GuanxianAnxian faults, lie in the southeastern half of the Longmen Shan belt, whose width is about $50 \mathrm{~km}$ (not including structures in the foreland within the western Sichuan basin; Fig. 1). Interpretation of seismic reflection profiles, field mapping, and distribution and fault plane solutions of aftershocks indicates that the Longmen Shan belt is comprised of a complex set of southeast-verging reverse faults [e.g., Hubbard and Shaw, 2009; Hubbard et al., 2010]. Some of these faults can be traced down to a depth of about $20 \mathrm{~km}$. At this depth, modeling of geodetic data suggests that the reverse faults merge into a low-angle thrust that extends tens of kilometers farther westward (Wang et al., 2011).

In addition to the references cited so far, there are voluminous studies of the Wenchuan sequence in the past three years, including special issues of journals [e.g., Yin, 2010 and this issue]. Yet most studies mentioned historical seismicity only in passing. Recently, Wang et al. (2011) selectively showed isoseismals for five historical events and three of them, all with estimated magnitude of 6.2 and above, clearly occurred along the Longmen Shan belt (events 1, 6, and 7; Table 1 and Fig. 1). Curiously, these authors wrote that "the Longmen Shan had experienced no documented large earthquakes". 


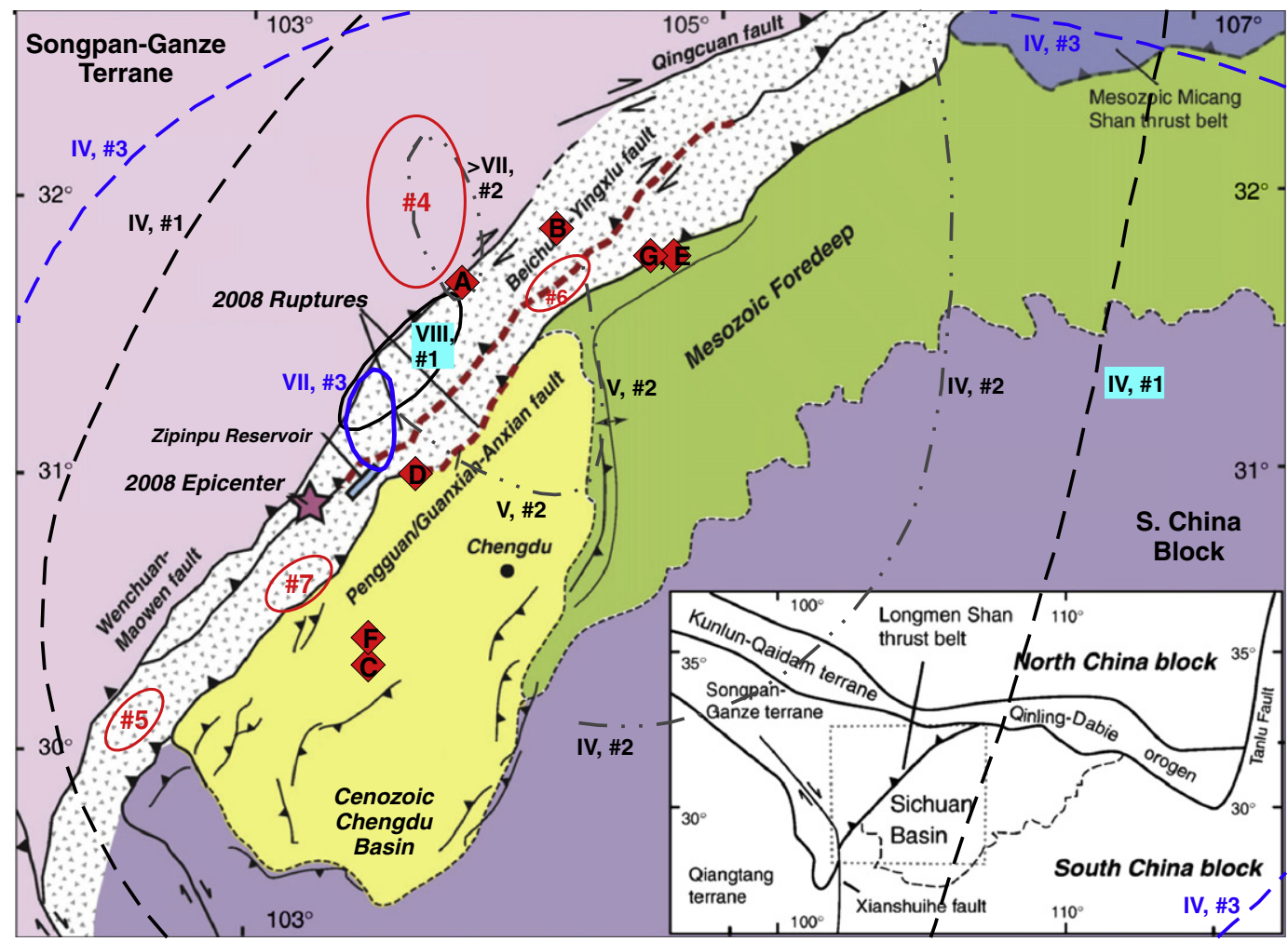

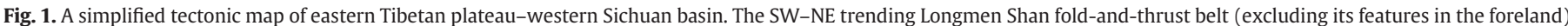

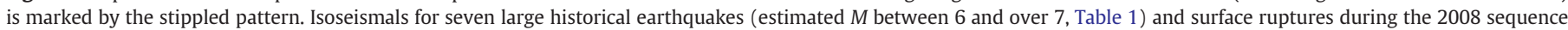

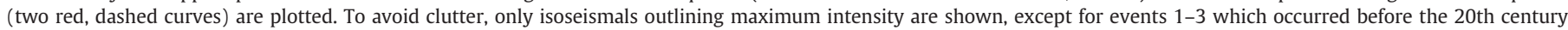

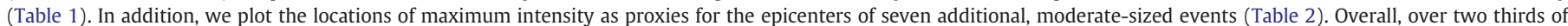

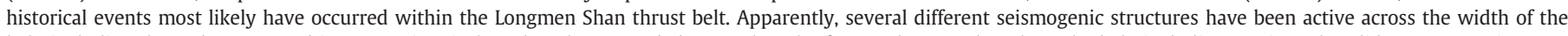

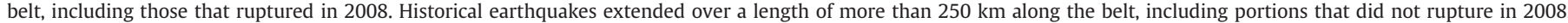
Base map is modified from Jia et al. (2006) and Yin (2010).

Trenching along the surface ruptures associated with the 2008 event showed that great events have most likely occurred in the distant past, with a long recurrence interval of tens of thousands of years [e.g., Ran et al., 2010]. Searching for great historical events, an important direction of research in its own right, is too narrow a perspective; as we shall show in this short note that a comparison between historical accounts of seismicity and the seismogenic zones of the 2008 Wenchuan sequence provides an additional source of information and also points to new questions on seismogenesis along the Longmen Shan fold-and-thrust belt.

Table 1

Large historical earthquakes of interest.

\begin{tabular}{|c|c|c|c|c|c|c|}
\hline Event & Date & $\begin{array}{l}\text { Lat. } \\
\left({ }^{\circ} \mathrm{N}\right)\end{array}$ & $\begin{array}{l}\text { Long. } \\
\left({ }^{\circ} \mathrm{E}\right)\end{array}$ & Magnitude & $\begin{array}{l}\text { Area with } \\
\text { intensity } \\
\text { IV or above } \\
\left(\text { in } 10^{6} \mathrm{~km}^{2} \text { ) }\right.\end{array}$ & References \\
\hline 1 & $\begin{array}{l}\text { April 21, } \\
1657\end{array}$ & 31.4 & 103.7 & $\sim 6.5$ & 0.21 & $\mathrm{a}, \mathrm{b}$ \\
\hline 2 & Sept. 4,1713 & 32.0 & 103.8 & $\sim 7$ & 0.13 & $\mathrm{a}, \mathrm{b}$ \\
\hline 3 & Feb. 23, 1748 & 31.2 & 103.6 & $\sim 6$ & 0.24 & a, b \\
\hline 4 & Aug. 25, 1933 & 32.0 & 103.7 & $>7$ & $N / A^{f}$ & $c, d$ \\
\hline 5 & June 12,1941 & 30.1 & 102.5 & 6.0 & $N / A^{f}$ & d, e \\
\hline 6 & Feb. 8, 1958 & 31.7 & 104.3 & 6.2 & $N / A^{f}$ & $c, d$ \\
\hline 7 & Feb. 24, 1970 & 30.6 & 103.2 & 6.2 & $N / A^{f}$ & c, d \\
\hline
\end{tabular}

a Li et al. (1990); ${ }^{\mathrm{b}} \mathrm{Gu}$ et al. (1983); ${ }^{\mathrm{C} C h e n ~ e t ~ a l . ~(1994) ; ~}{ }^{\mathrm{d}}$ Wen et al. (2009); ${ }^{\mathrm{e} W a n g}$ et al. (2009); ${ }^{\mathrm{f}}$ magnitude determined by instrumental data.

\section{Sources of information}

Spatial distribution of earthquake intensity has been a longstanding, useful tool for studying seismic hazard, with successful results in estimating the location and the magnitude of many earthquakes [e.g., Ambraseys and Melville, 1982; Atkinson and Wald, 2007; Bakun and Wentworth, 1997]. For recent earthquakes, such maps can be produced in near real-time as the public can report, via mobile communication devices, the severity of damage in their neighborhood immediately after an earthquake. Under the Community Internet Intensity Map project of the US Geological Survey, an interesting example is the recent, newsworthy (M 5.8), intra-plate earthquake of August 23, 2011 in Virginia near Washington, D.C. Within an hour 5000 reports had been received, and after $8 \mathrm{~h}$ the number increased to 12,500. (http://earthquake.usgs.gov/ earthquakes/dyfi/events/se/082311a/us/index.html).

For historical earthquakes in general, isoseismals are generally the only source that contains some quantifiable information [e.g., Stover and Coffman, 1993]. For earthquakes in Asia, the extensive written history of China has been the basis for one of the most complete and the longest accounts of historical seismicity [e.g., Gu et al., 1983]. To the first order, isoseismals, particularly that of maximum intensity, are a proxy for the location, the overall trend, and the length of earthquake rupture in the crust. For instance, Chen and Molnar (1977) made extensive use of macroseismic observations in a study of the 12 largest $(M \sim 7.6$ or greater) earthquakes in central Asia between 1911 and 1967. They showed that in general terms, the location of maximum intensity and the shape and the extent of isoseismals gave estimates of corresponding properties of earthquake rupture that are consistent with estimates from independent sources of information such as surface rupture of co-seismic faulting, 
distribution of carefully relocated aftershocks, and seismic moments determined from spectra of long-period surface waves.

For historical seismicity used in this study, we rely mainly on three sources of information. First is the comprehensive compilation of Chinese seismicity by Gu et al. (1983). This compendium covers the period between $1831 \mathrm{BCE}$ and $1969 \mathrm{CE}$. For each notable event ( $M \sim 4.8$ or greater), it gives the date, the estimated epicenter (to $0.1^{\circ}$ in latitude and longitude), maximum intensity (in modified Mercalli scale, $M M)$, and estimated magnitude. In addition, it provides a summary of overall damage caused by the event, followed by a list of similar information as reported at major towns or villages. In some cases an isoseismal map is also shown, but in general such maps are much simplified with little detail.

Second, for the past 500 years or so, a particularly noteworthy collection of reports, in the form of an atlas is available [Li et al., 1990]. The starting point of this atlas is the catalog of $\mathrm{Gu}$ et al. (1983), with subsequent modifications and corrections. A total of 334 events are included, with 183 detailed maps showing the distribution of isoseismals. Furthermore, it gives a brief summary of damage associated with each event and key literature. Neither sources, nor any other publications that are available to us, gave enough details to attempt further analysis such as that of Bakun and Wentworth (1997). Nevertheless, for eight significant events that occurred since 1900, it is possible to compare locations of epicenters estimated from intensity data alone with those determined from instrumental data. The differences are at most about $15 \mathrm{~km}$, insignificant considering the finite size of rupture during a major earthquake.

Prior to the overthrow of the Chinese imperial political system in 1911, there was no drastic change in major factors that affect estimated magnitude from intensity, such as the style of buildings and the population density, in the Sichuan basin during the Qing dynasty (1644-1911). As such, it is our assessment that relative values of estimated magnitude shown in Tables 1 and 2 are reliable. There is no obvious way to evaluate the absolute value of estimated magnitudes. However, this is a secondary issue as precise magnitudes are not necessary to establish the active nature of the Longmen Shan fold-and-thrust belt.

Equally important, locations, both current and historic, of towns and large villages, are plotted and labeled by Li et al. (1990); as human geography changes continually over the long history of China. This aspect is critical to place historical accounts in their correct geographic coordinates. As an example, Fig. 2 shows a small portion of the isoseismal map for event 1 (Table 1), as it appeared on $\mathrm{p}$. 22 of Li et al. (1990). Current names of locations and the same information at the time of the earthquake are labeled in brown and black, respectively. Notice that the location of the city of Wenchuan, whose name the 2008 sequence bears, has changed by some $18 \mathrm{~km}$ to the NE over the past 350 years.

Third, the more recent summaries of Chen et al. (1994), Wen et al. (2009), and Wang et al. (2010) for the Longmen Shan area filled a gap between 1911 and 1976 when the coverage by Li et al. (1990) stopped and routine reports of centroid-moment tensor solutions based on digital seismograms were yet to begin.

Table 2

Moderate-sized historical earthquakes of interest.

\begin{tabular}{llllll}
\hline Event & Date & Lat. $\left({ }^{\circ} \mathrm{N}\right)$ & Long. $\left({ }^{\circ} \mathrm{E}\right)$ & Approx. magnitude $^{\mathrm{a}}$ & References \\
\hline A & Sept. 15, 1488 & 31.7 & 103.9 & 5.5 & b, c \\
B & Feb. 14, 1597 & 31.9 & 104.3 & 5 & b, c \\
C & March, 1734 & 30.3 & 103.5 & 5 & d, e \\
D & Dec. 13, 1787 & 31.0 & 103.7 & 4.8 & d, e \\
E & May 12, 1879 & 31.8 & 104.8 & 5 & b, c \\
F & August, 1900 & 30.4 & 103.5 & 5 & d, e \\
G & Aug. 18, 1913 & 31.8 & 104.7 & 5 & b, c
\end{tabular}

${ }^{a}$ For events prior to 1900 , instrumental data are unavailable and magnitudes are estimated from reports of intensity at isolated locations. ${ }^{\mathrm{b}} \mathrm{Chen}$ et al. (1994); 'Wen et al. (2009); ${ }^{\mathrm{d}} \mathrm{Li}$ et al. (1990); ${ }^{\mathrm{e}} \mathrm{Gu}$ et al. (1983).

\section{Results and discussions}

Near the source zone of the 2008 Wenchuan sequence, we found a total of 14 historical events that are particularly relevant (Tables 1 and 2). Using a simplified tectonic map of eastern Tibetan plateau western Sichuan basin as an underlay, Fig. 1 compares the isoseismals for seven large historical earthquakes (estimated $M$ between 6 and over 7, Table 1) and surface ruptures during the 2008 sequence. In addition, we plot the locations of maximum intensity as proxies for the epicenters of seven additional, moderate-sized events (Table 2). While parts of this collection of information existed in the literature, Fig. 1 is the first comprehensive compilation of historical seismicity, surface ruptures associated with the 2008 sequence, and tectonic context of the Longmen Shan fold-and-thrust belt.

Overall, ten out of 14 historical events most likely have occurred along the Longmen Shan thrust belt (only events 2, 4, C, and F are exceptions). Estimated locations of epicenters form an approximately linear pattern that is sufficient to delineate the overall northeastsouthwest (NE-SW) trend of the Longmen Shan belt. Furthermore, the long axes of isoseismals for four large events are also subparallel to this trend which can be taken as a rough estimate of the strike of the seismogenic zones (Fig. 1; events 1, 5-7).

Whether some of these ten events occurred along different seismogenic structures, and the relationship between these structures and the seismogenic zones of the 2008 sequence are difficult to evaluate: Without instrumental data, precise locations of historical earthquakes are impossible to determine. Nevertheless, several pieces of evidence suggest that more than one seismogenic structure has been active over the past 500 years. For instance, event No. 1 apparently occurred near the Wenchuan-Maowen fault along the northwestern edge of the Longmen Shan belt where the width of this belt is about $50 \mathrm{~km}$. Considering that the density of population has always been much higher along the southeastern edge of the belt where topographic elevation and relief are low, it stands to reason that the most severe damage, therefore probably also the seismogenic zone, indeed occurred along the NW half of the Longmen Shan belt. Were this event to have occurred farther to the SE, the region of heaviest damage should be near the SE range-front of the Longmen Shan, as was clearly observed during the 2008 sequence.

Moreover, another moderate-sized event (" $A$ " in Fig. 1), apparently occurred near event 1 along the same structure trend defined by the well-documented Wenchuan-Maowen reverse fault. The most straightforward interpretation is that both events 1 and A occurred close to, if not right along the Wenchuan-Maowen fault. It certainly seems unlikely that these two events are associated with the Pengguan/Guanxian-Anxian fault but one cannot rule out that they may have occurred along the Beichuan-Yingxiu fault (both faults ruptured in 2008; Fig. 1).

Based on similar reasoning, events D, G, E, and perhaps also No. 7 , appear to be associated with the Pengguan/Guanxian-Anxian fault, of which a segment of about $50 \mathrm{~km}$ in length ruptured in 2008. Otherwise, it would be quite fortuitous that over a distance of 100 to $150 \mathrm{~km}$, several events just happen to lie along a well-known range-front fault. It is unlikely that the fault has nothing to do with these historical earthquakes. For event No. 3, the region of maximum intensity fell within the Longmen Shan thrust belt, yet the trend of isoseismal is roughly north-south $(\mathrm{N}-\mathrm{S})$, oblique to the overall trend of the main structures (NE-SW; also cf. isoseismal of event No. 1 nearby, Fig. 1). Interestingly, this is about the same region where a concentrated belt of aftershocks, also trending $\mathrm{N}-\mathrm{S}$, occurred after the main shock in 2008 . Fault plane solutions of the aftershocks show mainly strike-slip faulting [e.g., Cai et al., 2011; Wang et al., 2009], suggesting that this seismic belt is an active transfer fault between the Beichuan-Yingxiu and the WenchuanMaowen faults (Fig. 1).

Overall, in the past 500 years, ten known earthquakes scattered along the entire length of the Longmen Shan belt. As such, it is 


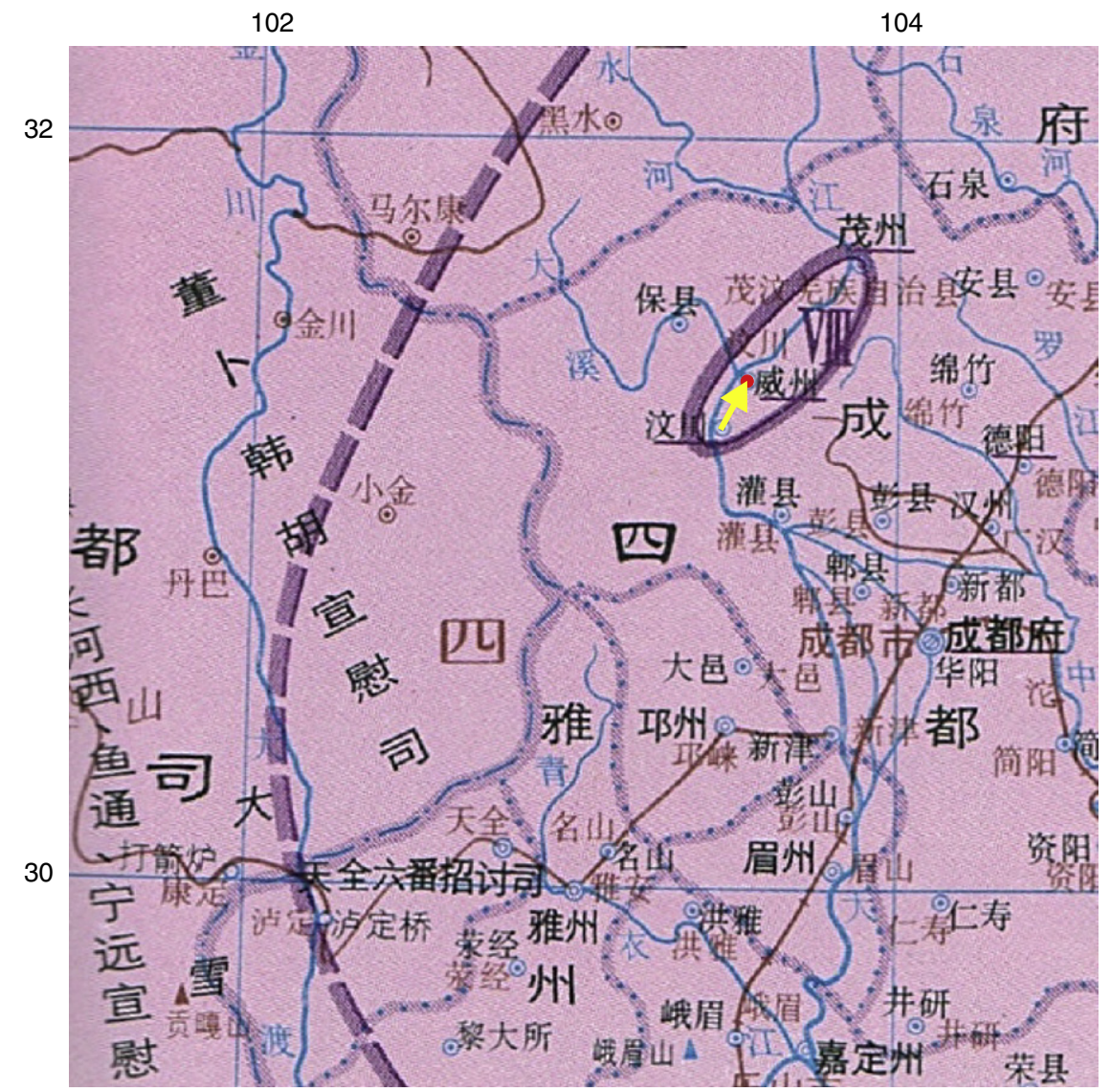

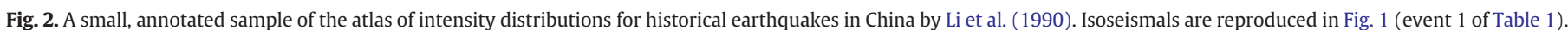

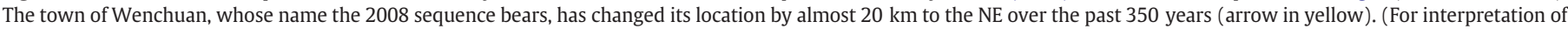
the references to color in this figure, the reader is referred to the website of this article.)

perhaps not a complete surprise that the great sequence of 2008 took place, even though events of comparable size may not have occurred in the past few thousand years (see Appendix A for further discussions). Moreover, historical events that clearly occurred along the Longmen Shan belt, but away from the rupture associated with the 2008 sequence (e.g., events 5 and 7) point to potential seismic hazard elsewhere near the western margin of the heavily populated Chengdu basin (Fig. 1). Since the locations of events 5-7 are determined by instrumental data, the observation that these epicenters fell close to centers of isoseismals for regions of maximum intensity lends further credence to the utility of historical earthquake accounts in this particular part of China. To this end, event 6 is a forerunner of large slip on the Beichuan-Yingxiu fault in 2008. Both event 5 and 7 seem to have occurred in the middle of the SW potion of the Longmen Shan belt which did not rupture in 2008 but is clearly active.

Two large events, 2 and 4 (Table 1), clearly occurred to the north of the Longmen Shan thrust belt, as the latter event's location was also determined from instrumental data. The fact that isoseismals of these two events largely overlap corroborates the reliability of information from event No. 2 which occurred almost 300 years ago (Fig. 1 and Table 1). Moreover, repeated occurrence of significant earthquakes indicates a noteworthy seismogenic zone. The consistent trend of isoseismals points to a roughly north-south trending fault, extending along the $104^{\circ} \mathrm{E}$ meridian to beyond $32^{\circ} \mathrm{N}$ (Fig. 1). This inference is supported by the occurrence of sparse aftershocks in 2008 along the same belt, where the fault plane solution of one large aftershock shows right-lateral, strike-slip faulting (Cai et al., 2011). Taken at face value, the configuration of major faults in this area suggests a $\mathrm{N}-\mathrm{S}$ trending transfer fault that connects the Wenchuan-Maowen and the Qingchuan faults (Fig. 1). At any rate, events Nos. 2 and 4 attest to a region of major seismic hazard to the north of Longmen Shan, as the maximum intensity has been estimated by Li et al. (1990) to reached IX during event No. 2 in 1713.

Finally, at $M M \sim I V$, the isoseismals are noticeably asymmetric in Fig. 1. The area of damage is much larger to the SE of the source zones, in the tectonically stable Sichuan basin, than that to the NW, on the actively deforming eastern Tibetan plateau (Fig. 1). Since the overall trend of the Longmen Shan belt is SW-NE, directivity during rupture propagation is unlikely to be the main cause of asymmetry in the distribution of intensity. Instead, low attenuation in stable areas of the continent is a probable explanation.

Strong effects of attenuation on the distribution of seismic intensity are particularly well-demonstrated in the United States: The area affected by intensity VIII and above during the 1811-1812 New Madrid sequence in cratonic Midwest is more than five times greater than that associated with the 1906 San Francisco earthquake - an event of roughly comparable seismic moment but which occurred along the North America-Pacific plate boundary [e.g., Atkinson and Wald, 2007; Bakun and Wentworth, 1997]. Recently Hough and Page (2011) suggested that moment releases during the 1811-1812 sequence were smaller than originally estimated and some shaking may be a result of dynamic triggering of seismicity away from the New Madrid zone. Even so, the contrast in areas of strong shaking is still striking between eastern and western US. In this regard, the two moderate-sized events ( $\mathrm{C}$ and F, Fig. 1 and Table 2) that apparently occurred along the foreland of the Longmen Shan within the Chengdu basin indicate the potential presence of notable active faults below this densely populated basin. 


\section{Concluding remarks}

More than a dozen well-documented, damaging historical earthquakes point to the active nature of the entire Longmen Shan fold-and-thrust belt, even though no more than four historical events seem to have occurred on the same splays of reverse faults that ruptured the surface in 2008. In particular, the southern part of the belt, which did not rupture in 2008, has also been seismically active in the past few hundred years. Furthermore, other structures in the hinterland of this belt, such as the Wenchuan-Maowen fault and what appear to be transfer faults that connect major reverse faults, have historical earthquakes whose rupture length approaches about $50 \mathrm{~km}$.

In the foreland of this belt, asymmetry of isoseismals suggests that attenuation is particularly low in the stable Sichuan basin. Moreover, moderate sized historical earthquakes have occurred in the foreland basin which is heavily populated.

\section{Acknowledgements}

We thank R. Engdahl and P.-Z. Zhang who invited Chen to attend the 2011 Bi-Lateral Workshop under the Sino-US Earthquake Studies Protocol. Zhang and many of his colleagues kindly led three field excursions to observe active tectonic features and damage associated with the 2008 sequence. As a result, Chen was able to make Gigapan images, a mosaic of hundreds of high-resolution photographs near Beichuan (https://netfiles.uiuc.edu/wpchen/shared/Reprints_Wang-Ping_CHEN/ GigaPanLinks.txt). The 2011 CIDER (Cooperative Institute for Dynamic Earth Research; under US NSF grant EAR 09-68979) summer program brought the two authors together for this collaboration. We thank two anonymous reviewers whose suggestions improved the manuscript. This research was supported by US NSF grants EAR99-09362 ("HiCLIMB"), EAR05-51995, and EAR06-35419. Any opinions, findings and conclusions or recommendations expressed in this material are those of the authors and do not necessarily reflect those of the NSF.

\section{Appendix A}

In this section, we provide brief, additional discussions on the distribution of seismicity in space and time. While the Sichuan region has been densely populated for thousands of years, prior to the work of Li et al. (1990), changes in the locations of population centers over time have not been accounted for carefully in catalogs of historical seismicity [e.g., Gu et al., 1983]. As such, we focused on the time period after 1644 (inception of the Qing dynasty) when the coverage of atlas by Li et al. begins. Table 2 included two moderate-sized events prior to 1644 simply because they have been discussed in recent literature (Chen et al., 1994; Wen et al., 2009).

The main text emphasized the distribution of seismicity in space, as spatial pattern alone is sufficient to establish our key conclusion:

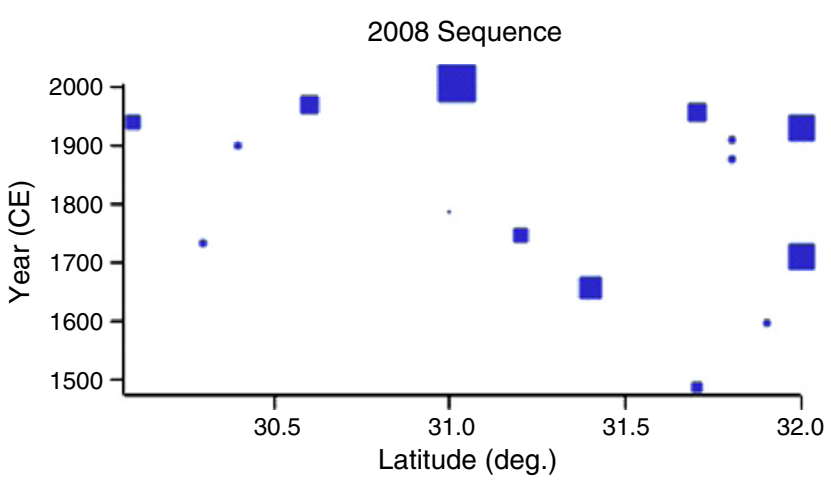

Fig. A1. A plot of seismicity over space and time (Tables 1 and 2, plus the 2008 sequence). Sizes of symbols are proportional to magnitudes.
The entire Longmen Shan fold-and-trust belt is seismically active prior to the occurrence of the 2008 Wenchuan sequence. Whether historical seismicity has a discernible temporal pattern is much less clear. Fig. A1 suggests that the northern half of the fold-and-trust belt has been more active in the past, and the 2008 sequence occurred near the southern terminus of the historically very active segment.

\section{References}

Ambraseys, N., Melville, C., 1982. A History of Persian Earthquakes. Cambridge Univ. Press.

Atkinson, G., Wald, D., 2007. Modified Merclli intensity: a surprisingly good measure of ground motion. Seismological Research Letters 78, 362-368.

Bakun, W.H., Wentworth, C.M., 1997. Estimating earthquake location and magnitude from seismic intensity data. Bulletin of the Seismological Society of America 87 (6), 1502-1521.

Bird, P., 1991. Lateral extrusion of lower crust from under high topography in the isostatic limit. Journal of Geophysical Research 96, 10,275-10,286.

Burchfiel, B.C., Chen, Z., Liu, Y., Royden, L., 1995. Tectonics of the Longmen Shan and adjacent regions, Central China. International Geology Review 37, 661-735.

Cai, C., et al., 2011. Spatial distribution and focal mechanism solutions of the Wenchuan earthquake series: results and implications. Earthquake Science 24, 115-125.

Chen, W.-P., Molnar, P., 1977. Seismic moments of major earthquakes and the average rate of slip in Asia. Journal of Geophysical Research 82, 2945-2969.

Chen, S.F., Wilson, C.J.L., Deng, Q.D., Zhao, X.L., Lou, Z.L., 1994. Active faulting and block movement associated with large earthquakes in the Min Shan and Longmen Mountains, northeastern Tibetan Plateau. Journal of Geophysical Research 99 (B12), 24,025-24,038.

Chen, W.-P., et al., 2010. Shear-wave birefringence and current configuration of converging lithosphere under Tibet. Earth and Planetary Science Letters 295 (1-2), 297-304 http://dx.doi.org/10.1016/j.epsl.2010.04.017.

Chen, W.-P., et al., 2012. Rheology of the continental lithosphere: progress and new perspectives. Gondwana Research 21, 4-18 http://dx.doi.org/10.1016/j.gr.2011.07.013.

Densmore, A.L., et al., 2007. Active tectonics of the Beichuan and Pengguan faults at the eastern margin of the Tibetan Plateau. Tectonics 26, TC4005 http://dx.doi.org/ $10.1029 / 2006$ TC001987.

Gu, G., et al., 1983. Catalog of Chinese Earthquakes: 1831 BCE-1969 CE (in simplified Chinese). Sci. Pub. House, Beijing.

Hough, S.E., Page, M., 2011. Toward a consistent model for strain accrual and release for the New Madrid Seismic Zone, central United States. Journal of Geophysical Research 116 (B03311) http://dx.doi.org/10.1029/2010JB007783.

Hubbard, J., Shaw, J.H., 2009. Uplift of the Longmen Shan and Tibetan plateau, and the 2008 Wenchuan $(M=7.9)$ earthquake. Nature 458, 194-197.

Hubbard, J., Shaw, J.H., Klingher, Y., 2010. Structural setting of the $2008 \mathrm{Mw} 7.9$ Wenchuan, China earthquake. Bulletin of the Seismological Society of America 100 (5B), 2713-2735.

Jia, D., et al., 2006. Longmen Shan fold-thrust belt and its relation to the western Sichuan Basin in central China: new insights from hydrocarbon exploration. Bulletin of the American Association of Petroleum Geologists 90, 1425-1447 http:// dx.doi.org/10.1306/03230605076.

Li, Y., et al., 1990. Atlas of the Historical Earthquakes in China: the Qing Dynasty Period (in simplified Chinese). China Cartogr. Pub. House, Beijing.

Meade, B.J., 2007. Present-day kinematics at the India-Asia collision zone. Geology 35, 81-84

Nakamura, T., Tsuboib, S., Kaneda, Y., Yamanaka, Y., 2010. Rupture process of the 2008 Wenchuan, China earthquake inferred from teleseismic waveform inversion and forward modeling of broadband seismic waves. Tectonophysics 491 (1-4), 72-84.

Ran, Y., et al., 2010. Paleoseismic evidence and repeat time of large earthquakes at three sites along the Longmenshan fault zone. Tectonophysics 491, 141-153.

Royden, L.H., et al., 1997. Surface deformation and lower crustal flow in eastern Tibet. Science 276, 788-790.

Shen, Z.-K., Lu, J., Wang, M., Burgmann, R., 2005. Contemporary crustal deformation around the southeast borderland of the Tibetan plateau. Journal of Geophysical Research 110, B11409 http://dx.doi.org/10.1029/2004JB003421.

Stover, C.W., Coffman, J.L., 1993. Seismicity of the United States, 1568-1989. U.S. Geological Survey Professional Paper 1527.

Wang, Q.-C., Chen, Z., Zheng, S., 2009. Spatial segmentation characteristic of focal mechanism of aftershock sequence of Wenchuan earthquake. Chinese Science Bulletin 54, 2263-2270.

Wang, H., Liu, M., Shen, X., Liu, J., 2010. Balance of seismic moment in the SongpanGanze region, eastern Tibet: implications for the 2008 Great Wenchuan earthquake. Tectonophysics 491, 154-164.

Wang, Q., et al., 2011. Rupture of deep faults in the 2008 Wenchuan earthquake anduplift of the Longmen Shan. Nature Geoscience http://dx.doi.org/10.1038/NGE001210.

Wen, X., Zhang, P., Du, F., Long, F., 2009. The background of historical and modern seismic activities of the occurrence of the 2008 Ms 8.0 Wenchuan, Sichuan, earthquake (in simplified Chinese). Chinese Journal of Geophysics 52, 444-454.

$\mathrm{Xu}, \mathrm{X}$.-W., et al., 2009. Coseismic reverse- and oblique-slip surface faulting generated by the $2008 \mathrm{Mw} 7.9$ Wenchuan earthquake, China. Geology 37 (6), 515-518.

Yin, A., 2010. A special issue on the great 12 May 2008 Wenchuan earthquake (Mw 7.9): observations and unanswered questions. Tectonophysics 491, 1-9.

Yin, A., Harrison, T.M., 2000. Geologic evolution of the Himalayan-Tibetan orogen. Annu. Rev. Earth Planet. Sci. 28, 211-280. 